\title{
Variasi Temporal Kontribusi Aliran Dasar pada Mataair Epikarst di Kawasan Karst Gunungsewu, Indonesia
}

\author{
Muhammad Naufal ${ }^{1,2 *}$, Margaretha Widyastuti ${ }^{1,2}$, Ahmad Cahyadi ${ }^{1,2}$, Fajri \\ Ramadhan', Indra Agus Riyanto ${ }^{3}$, Khansa Sitostratufana Arsy An nisa', Tjahyo \\ Nugroho Adji ${ }^{1,2}$ \\ ${ }^{1}$ Karst Research Group, Faculty of Geography, Universitas Gadjah Mada, Indonesia \\ ${ }^{2}$ Environmental Geography Department, Faculty of Geography, Universitas Gadjah \\ Mada, Indonesia \\ ${ }^{3}$ Program on Planning and Management of Coastal Area and Watershed, Faculty of \\ Geography, Universitas Gadjah Mada, Indonesia \\ "naufalmuhammad@mail.ugm.ac.id
}

\begin{abstract}
Aliran yang bergerak secara perlahan (infiltrasi) yang selanjutnya dikenal dengan aliran mantap atau aliran dasar (baseflow) merupakan satu-satunya pemasok air pada aliran bawah tanah pada bentuklahan karst ketika musim kemarau. kontribusi karakter aliran ini tentunya sangat berperan besar dalam mendukung penyediaan air bersih. Pemahaman terkait dengan karakteristik aliran dasar secara detail memiliki urgensi yang sangat tinggi untuk dikaji. Penelitian ini bertujuan untuk melakukan analisis temporal kontribusi aliran dasar pada mataair epikarst di Kawasan Karst Gunungsewu, Indonesia. Lokasi studi adalah Mataair Guntur yang menempati Sub-sistem Panggang. Data yang digunakan dalam penelitian ini meliputi data aliran dari Mataair Guntur selama satu tahun. Metode yang digunakan dalam penelitian ini adalah automated base flow separation by digital filtering. Hasil analisis menunjukkan bahwa konstribusi aliran dasar di Mataair Guntur adalah antara 79,57\% sampai dengan 93,96\%.
\end{abstract}

\section{Introduction}

Karst merupakan sebuah istilah internasional (Fatchurohman, dkk, 2017) yang digunakan untuk mendeskripsikan sebuah bentuklahan yang spesial (Ford dan Williams, 2007) berupa mofologi yang unik (Milanovic, 2015) dan karakteristik hidrologi yang unik pula (Cahyadi, 2014). Keberadaan lingkungan karst yang unik terbentuk karena kontrol batuan yang bersifat mudah larut oleh air (Beynen, 2011), seperti batuan karbonat, evaporit dan juga kuarsit. Bentuklahan karst juga sangat identik dengan keberadaan gua dan sistem hidrogeologi bawah tanahnya.

Keberadaan bentuklahan karst berdampak positif terhadap potensi sumberdaya yang dimiliki, diantaranya yaitu sumberdaya mineral, (Adji, dkk, 1999) sumberdaya wisata, dan juga sumberdaya air. Mengerucut pada ketersediaan sumberdaya air di karst, diketahui bahwa kebutuhan air penduduk dunia kurang lebih mencapai 20-25\% bersumber dari air yang berasal dari karst (Ford dan Williams, 2007). Dengan demikian, kontribusi karakter aliran air pada bentuklahan karst tentunya sangat berperan besar dalam mendukung kehidupan masyarakat disekitarnya.

Tipe aliran di akuifer terdiri dari aliran rembesan (diffuse), sistem aliran rekahan (fissure), dan sistem aliran lorong (conduit) ((White, 1969; Atkinson, 1977; Atkinson, 1985). Aliran diffuse merupakan komponen aliran yang mengisi sungai bawah tanah yang mengalir melalui rongga antar butir batuan. Komponen aliran ini diimbuh dari air hujan yang telah terinfiltrasi. Sementara itu, aliran fissure 
Paper ini merupakan versi Bahasa Indonesia dari paper kami yang diterbitkan di https://www.e3sconferences.org/articles/e3sconf/abs/2019/51/e3sconf icenis2019 01014/e3sconf icenis2019010 14.html

merupakan komponen aliran yang mengisi sungai bawah tanah dan alirannya berasal dari celah bebatuan karbonat yang berukuran 102-104 mm. Aliran ini bersifat turbulen, terutama ketika terjadi banjir. Adapun aliran conduit merupakan aliran yang mengisi sungai bawah tanah, dengan asal aliran yaitu melalui lorong pelarutan dengan ukuran yang besar.

Berdasarkan definisi dari ketiga komponen aliran tersebut, maka aliran yang melewati rongga antar butir batuan yang bergerak secara perlahan selanjutnya dikenal dengan aliran diffuse. Komponen aliran ini merupakan pemasok air yang dominan pada aliran sungai bawah tanah pada bentuklahan karst ketika musim kemarau. Dengan demikian dapat diketahui, bahwa komponen aliran ini selalu ada di musim kemarau maupun di musim penghujan, meskipun besarannya fluktuatif.

Secara umum Karst Gunung Sewu merupakan representasi karst yang berkembang di lingkungan tropis (Adji dkk., 1999). Luasnya mencapai $3.300 \mathrm{~km}^{2}$ yang meliputi Propinsi DIY (sebagian Kabupaten Gunungkidul), Jawa Tengah (sebagian Kabupaten Wonogiri), dan Propinsi Jawa Timur (Sebagian Kabupaten Pacitan) (Gambar 1.) (Haryono, 2011; Haryono, Day, 2004). Dominasi penggunaan lahan Karst Gunung Sewu berupa tegalan (31.56\%), dan selebihnya merupakan penggunaan lahan lainnya (Wijayanti, dkk, 2017). Lokasi penelitian dipilih pada Mataair Guntur yang termasuk dalam bagian Karst Gunung Sewu bagian barat (Sub-sitem hidrogeologi Panggang). Adapun secara administratif Mataair Guntur masuk dalam Desa Girijati, Kecamatan Purwosari, Kabupaten Gunungkidul, D.I. Yogyakarta, Indonesia. Luasan daerah tangkapan Mataair Guntur sebesar 30.7 Ha (Widyastuti et al., 2018). Penelitian ini bertujuan untuk mengetahui variasi temporal aliran diffuse pada Mataair Guntur yang merupakan mataair epikarst di kawasan karst Gunugsewu. Penelitian ini diharapkan dapat memberikan gambaran terkait dengan karakter aliran diffuse pada mataair epikarst khususnya di kawasan karst tropis.

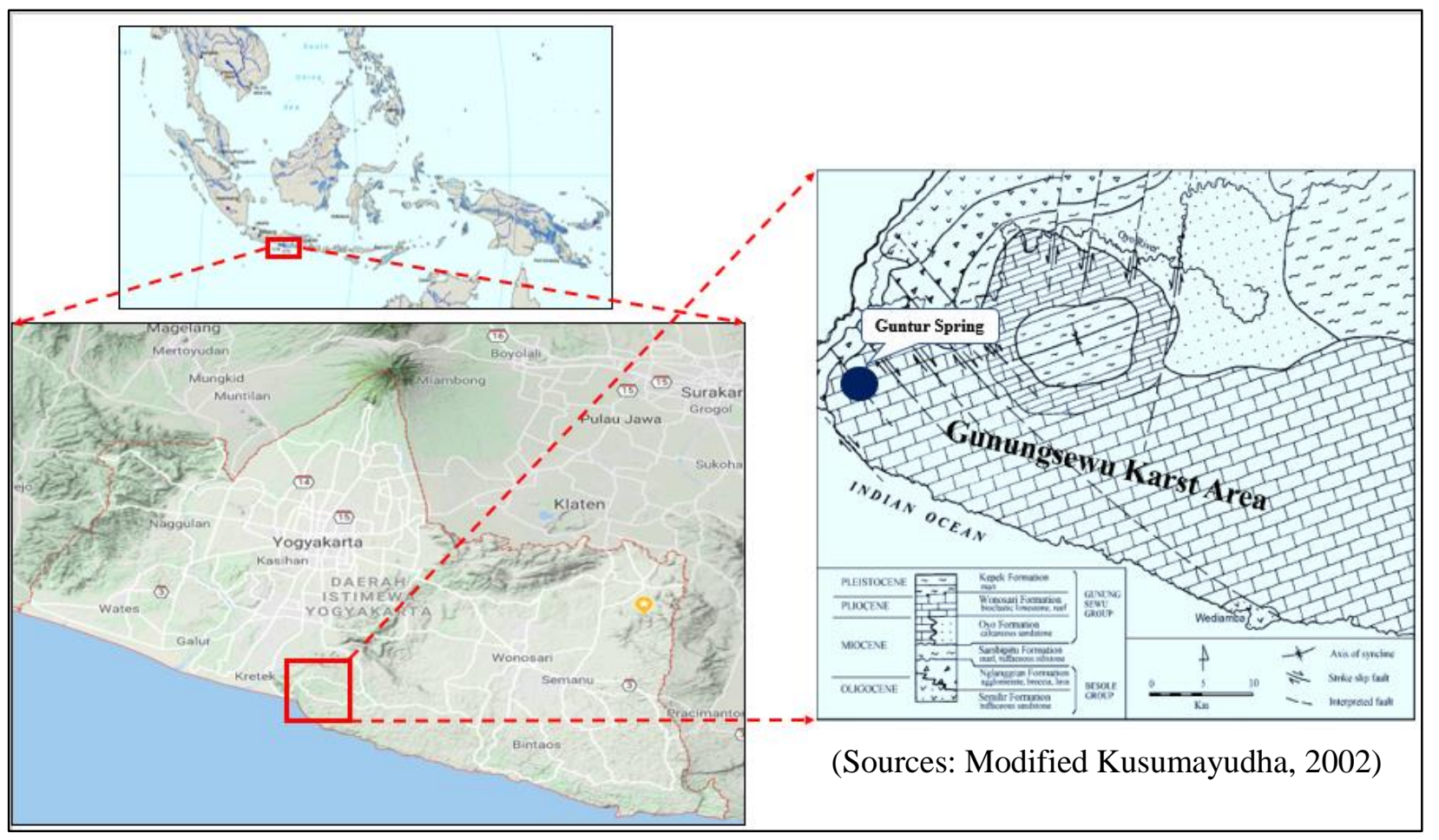

Fig 1. Research location, Guntur Spring as part Gunung Sewu Karst area

\section{Methodology}

Penelitian yang dilakukan merupakan experimental research, yakni menghimpun data yang sangat banyak (temporal) untuk selanjutnya dianalisis dan dielaborasi dengan teori yang ada hingga mengerucut pada suatu hipotesis tertentu. Adapun data utama yang dihimpun dalam penelitian ini berupa data tinggi muka air yang dicatat melalui water level data logger dan selanjutnya dikonversikan menjadi 
debit aliran dengan rating curve. Data tinggi muka air dihimpun selama 1 tahun yang dimulai bulan April 2018 hingga bulan Maret 2019.

Pengukuran untuk merepresentasikan periode debit kecil, menengah dan puncak dilakukan melalui pengukuran langsung di lapangan (pengukuran sesaat) selama 29 kali sebagai dasar pembuatan kurva hubungan debit dan tinggi muka air (rating curve). Dengan demikian, diketahui tingkat hubungan antara tinggi muka air dengan debit aliran yang dapat dilihat pada besarnya nilai $\mathrm{R}$ dari hasil korelasi pada kurva, dan juga didapatkan rumus persamaan hubungan antara tinggi muka air dengan debit.

Pemisahan aliran dasar selanjutnya dapat dilakukan berdasarkan hidrograf aliran yang sebelumnya telah terbentuk. Adapun menurut Schulz (1976) menyatakan bahwa pemisahan aliran dasar merupakan sebuah proses pemisahan antara komponen base flow dengan komponen Run Off. Metode pemisahan aliran dasar (base flow separation) dilakukan dengan menerapkan metode automated base flow separation by digital filtering (Eckhardt, 2005). Berikut adalah rumus pemisahan aliran dasar, melalui automated base flow separation by digital filtering

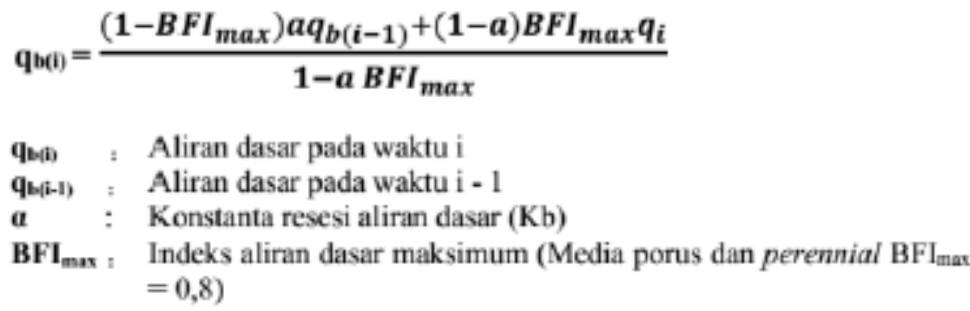

(1) (Eckhardt, 2005)

\section{Results and Discussion}

\section{Spring Hydrograph}

Penelitian yang dilakukan pada Mataair Guntur dilakukan selama 1 tahun dimulai dari bulan April 2018 hingga awal bulan April 2019. Alat pencatat ketinggian muka air di Mataair Guntur di atur dengan interval pencatatan 10 menit. Adapun pengukuran sesaat debit dan juga tinggi muka air dilapangan dilakukan sebanyak 29 kali untuk didapatkan persamaan melalui pembuatan kurva hubungan anara tinggi muka air dengan debit yang disebut rating curve. Berikut tabel pengukuran langsung debit dan tinggi muka air dan juga hasil rating curve di Mataair Guntur (Tabel 1 dan Gambar 1.)

Tabel 1. Pengukuran langsung tinggi muka air dan debit di lapangan

\begin{tabular}{|c|c|c|c|c|c|c|c|c|c|}
\hline \multirow[t]{2}{*}{ No } & \multicolumn{2}{|c|}{$\begin{array}{c}\text { Waktu } \\
\text { Pengukuran }\end{array}$} & \multirow[t]{2}{*}{$\begin{array}{c}\text { TMA } \\
\text { (meter) }\end{array}$} & \multirow[t]{2}{*}{$\begin{array}{l}\text { Debit } \\
(1 / d t)\end{array}$} & \multirow[t]{2}{*}{ No } & \multicolumn{2}{|c|}{$\begin{array}{c}\text { Waktu } \\
\text { Pengukuran }\end{array}$} & \multirow[t]{2}{*}{$\begin{array}{c}\text { TMA } \\
\text { (meter) }\end{array}$} & \multirow[t]{2}{*}{$\begin{array}{l}\text { Debit } \\
(\mathbf{l} / \mathbf{d t})\end{array}$} \\
\hline & Tanggal & Pukul & & & & Tanggal & Pukul & & \\
\hline 1 & $07 / 04 / 2018$ & 12.00 & 0.18 & 68.3606 & 16 & $19 / 01 / 2019$ & 03.06 & 0.39 & 1108.758 \\
\hline 2 & $13 / 05 / 2018$ & 11.00 & 0.09 & 12.864 & 17 & $20 / 01 / 2019$ & 04.27 & 0.37 & 941.4084 \\
\hline 3 & $12 / 05 / 2018$ & 10.00 & 0.09 & 94.43997 & 18 & $21 / 01 / 2019$ & 09.20 & 0.36 & 447.0346 \\
\hline 4 & $12 / 06 / 2018$ & 09.00 & 0.098 & 92.24369 & 19 & $22 / 01 / 2019$ & 14.08 & 0.35 & 470.7126 \\
\hline 5 & 03/08/2018 & 11.00 & 0.074 & 74.81963 & 20 & $23 / 01 / 2019$ & 19.57 & 0.34 & 361.8649 \\
\hline 6 & 04/09/2018 & 10.00 & 0.109 & 87.16452 & 21 & $13 / 02 / 2019$ & 02.55 & 0.322 & 341.7954 \\
\hline 7 & $10 / 10 / 2018$ & 12.00 & 0.099 & 92.24369 & 22 & $12 / 02 / 2019$ & 01.35 & 0.324 & 341.7954 \\
\hline 8 & $04 / 11 / 2018$ & 12.30 & 0.045 & 95.45521 & 23 & 01/03/2019 & 19.45 & 0.378 & 980.6337 \\
\hline
\end{tabular}


Paper ini merupakan versi Bahasa Indonesia dari paper kami yang diterbitkan di https://www.e3sconferences.org/articles/e3sconf/abs/2019/51/e3sconf icenis2019 01014/e3sconf icenis2019010 14.html

\begin{tabular}{cccccccccc}
$\mathbf{9}$ & $30 / 11 / 2018$ & 12.45 & 0.055 & 103.0917 & 24 & $07 / 03 / 2019$ & 02.25 & 0.361 & 944.6472 \\
$\mathbf{1 0}$ & $22 / 12 / 2018$ & 11.25 & 0.15 & 190.2383 & 25 & $16 / 03 / 2019$ & 01.50 & 0.412 & 1297.767 \\
$\mathbf{1 1}$ & $31 / 12 / 2018$ & 09.52 & 0.3 & 314.3292 & 26 & $17 / 03 / 2010$ & 22.40 & 0.472 & 1298.334 \\
$\mathbf{1 2}$ & $05 / 01 / 2019$ & 10.38 & 0.32 & 342.4542 & 27 & $18 / 03 / 2019$ & 07.30 & 0.464 & 1297.767 \\
$\mathbf{1 3}$ & $16 / 01 / 2019$ & 21.48 & 0.34 & 361.8649 & 28 & $24 / 03 / 2019$ & 08.30 & 0.397 & 980.6074 \\
$\mathbf{1 4}$ & $17 / 01 / 2019$ & 23.02 & 0.37 & 941.4084 & 29 & $06 / 04 / 2019$ & 09.50 & 0.257 & 326.6707 \\
$\mathbf{1 5}$ & $18 / 01 / 2019$ & 01.34 & 0.38 & 1042.128 & & & & & \\
\hline
\end{tabular}

Sources: Field measurment (2018-2019)

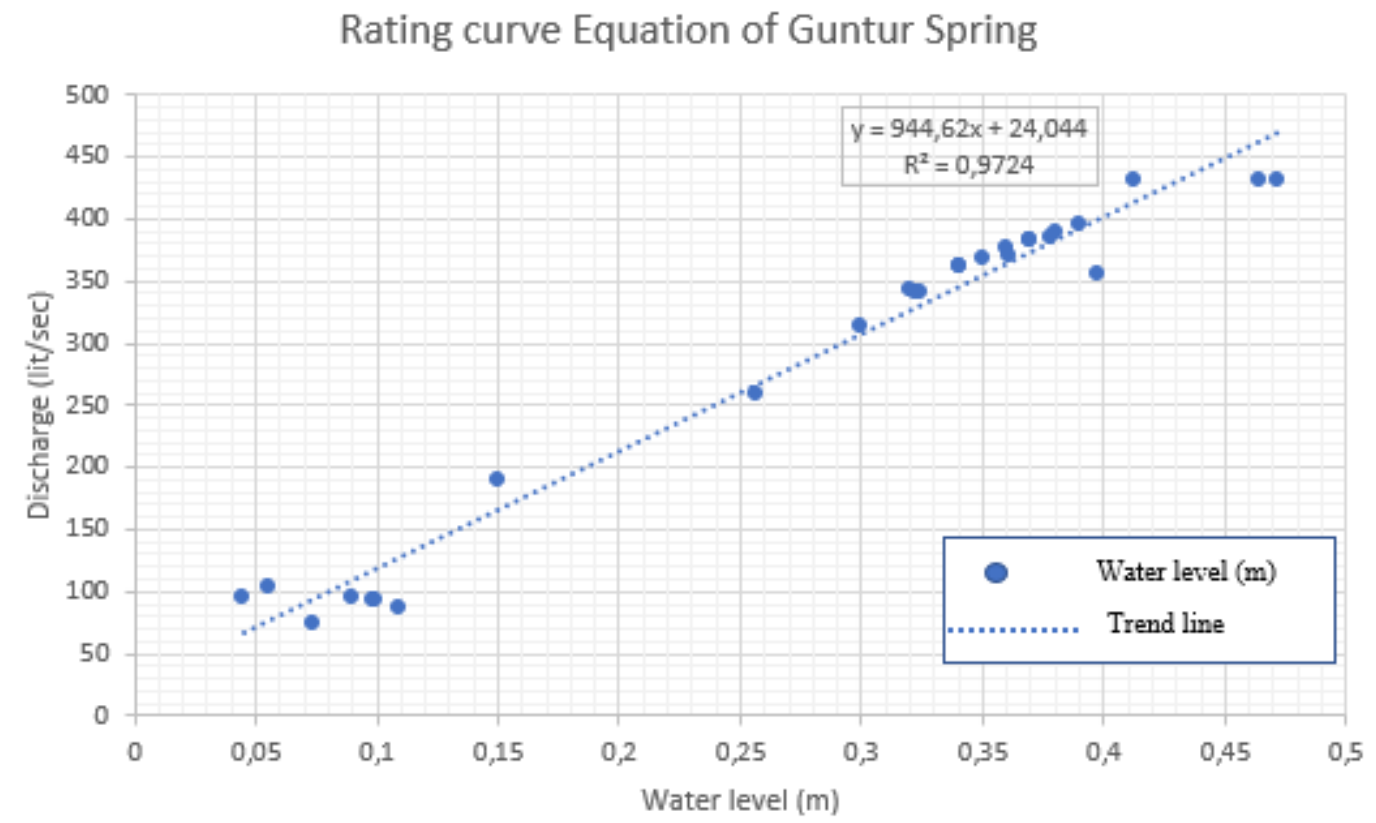

Fig. 2 Rating curve of Guntur Spring

Berdasarkan hasil penarikan trend line pada antara nilai tinggi muka air dengan besarnya debit yang diukur secara langsung dilapangan, didapatkan nilai $R$ pada rating curve sebesar 0.9724 , artinya derajat keterkaitan diantara 2 komponen semakin mendekati 1, yakni keduanya memiliki hubungan yang cukup kuat. Adapun persamaan yang dihasilkan yaitu $\mathbf{y}=\mathbf{9 4 4 . 6 2} \mathbf{x + 2 4 . 0 4}$. Berdasarkan persamaan tersebut, selanjutnya dapat disajikan hidrograf aliran dari Mataair Guntur sebagai berikut pada gambar 3, yang menunjukkan bahwa air selalu mengalir dari musim penghujan sampai musim kemarau, meskipun terdapat fluktuasi debit yang signifikan antara musim penghujan dan kemarau. 


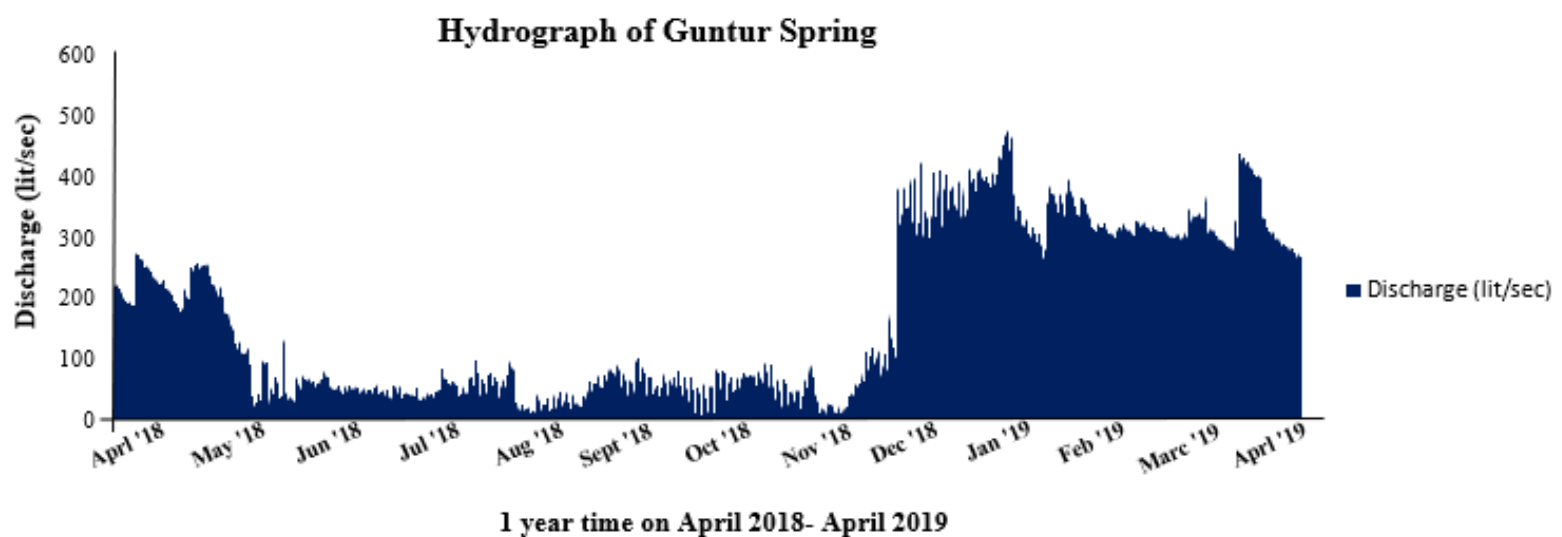

Fig 3. Hydrograph of Guntur Spring

Pemunculan Mataair Guntur berasal dari proses pemotongan topografi yang disebabkan karena adanya patahan Opak (Notosiswoyo and Kusumayudha (1998) dan selanjutnya memotong bagian utara dari perbukitan Karst Gunungsewu (Cahyadi, dkk, 2018b), diantarannya di sub-sistem hidrogeologi Panggang. Adapun debit terkecil dan terbesar selama penelitian masing-masing mencapai $7.56 \mathrm{lit} / \mathrm{sec}$ dan $504.23 \mathrm{lit} / \mathrm{sec}$, dengan debit rata-rata $169.14 \mathrm{lit} / \mathrm{sec}$. Kecilnya rata-rata debit yang terjadi pada Mataair Guntur menjadi salah satu ciri dari pemunculan mataair yang berada pada sub-hidrogeologi Panggang di Karst Gunung Sewu. Posisi Mataair Guntur yang berada di bagian atas dari perlapisan batugamping menjadikan salah satu penyebab lapisan diatasnya yang berperan sebagai lapisan penyimpan air yang tipis sehingga lebih lanjut berimbas pada simpanan airtanah yang juga dalam jumlah yang terbatas (kecil) (Cahyadi, dkk, 2018a). Sejalan dengan pernyataan yang dihasilkan dari penelitian Haryono (2011) dan Haryono, dkk (2017) bahwasannya Mataair sub-sistem Panggang didominasi dengan Mataair epikarst.

\section{Baseflow Characteristic of Guntur Spring}

Berdasarkan hidrograf aliran yang telah dihasilkan, didapatkan 9 banjir terpilih untuk mengidentifikasi karakteristik aliran dasar pada Mataair Guntur. Pemilihan banjir diasumsikan dapat merepresentasikan kondisi di saat awal penghujan hingga di akhir kemarau. Berikut (Tabel 2) karakteristik aliran pada Mataair Guntur yang meliputi besarnya debit puncak, kategori banjir, waktu aliran menuju encak $(\mathrm{Tp})$, lamanya aliran tinggal $(\mathrm{Tb})$ dan juga koefisien aliran dasar $(\mathrm{Kb})$.

Tabel 2. Karakteristik aliran pada banjir terpilih Mataair Guntur

\begin{tabular}{|c|c|c|c|c|c|c|}
\hline No. & Waktu & $\begin{array}{l}\text { Q max } \\
\text { (lit/sec) }\end{array}$ & kategori banjir & $\begin{array}{c}\text { Tp } \\
\text { (Hours) }\end{array}$ & $\begin{array}{c}\text { Tb } \\
\text { (Hours) }\end{array}$ & $\mathbf{K b}$ \\
\hline 1 & $07 / 04 / 2018$ & 279.56 & sedang & 1.16 & 205.82 & 0.990 \\
\hline 2 & 08/05/2018 & 159.56 & sedang & 30.16 & 188.00 & 0.990 \\
\hline 3 & $19 / 06 / 2018$ & 93.56 & rendah & 27.16 & 112.50 & 0.974 \\
\hline 4 & 26/06/2018 & 63.56 & rendah & 5.30 & 159.00 & 0.960 \\
\hline 5 & $28 / 11 / 2018$ & 209.56 & sedang & 1.83 & 55.60 & 0.991 \\
\hline 6 & $22 / 12 / 2018$ & 423.56 & tinggi & 3.60 & 117.60 & 0.999 \\
\hline 7 & 23/01/2019 & 402.56 & tinggi & 14.50 & 53.83 & 0.998 \\
\hline 8 & $18 / 03 / 2019$ & 504.23 & tinggi & 2.16 & 169.83 & 0.999 \\
\hline 9 & $24 / 03 / 2019$ & 392.56 & tinggi & 0.50 & 314.50 & 0.999 \\
\hline \multicolumn{4}{|c|}{ Average } & 9.60 & 152.96 & 0.990 \\
\hline
\end{tabular}

Sources: Data Processing (2019) 
Hasil pengolahan data (Tabel 1) melalui banjir terpilih untuk mengidentifikasi karakteristik aliran pada Mataair Guntur dihasilkan rata-rata waktu yang dibutuhkan untuk mencapai debit puncak selama 9.6 jam dengan waktu terlama sebesar 30.16 jam dan waktu tercepat selama 0.5 jam. Kondisi tersebut cukup relevan dengan kondisi banjir yang sedang berlangsung saat itu, yaitu ketika banjir pada kategori rendah hingga sedang, waktu yang dibutuhkan untuk mencapai debit puncak semakin lama, dan begitu juga sbealiknya. Adapun lamanya waktu tinggal air ( Tb) rata-rata pada 152.96 jam, dengan waktu terlama pada bulan saat terjadi hujan dan banjir pada kategori yang tinggi, dibuktikan dengan waktu terlama sebesar 314.50 jam terjadi pada kejadian banjir pada tanggal 24 maret 2019. Lebih lanjut, koefisien resesi pada aliran dasar Mataair Guntur rata-rata sebesar 0.990, artinya nilai tersebut menujukkan lambatnya pelepasan komponen aliran khususnya aliran dasar pada Mataair Guntur. Lebih jauh lagi semua kondisi tersebut mencerminkan bahwa komponen aliran pada Mataair Guntur didukung dengan sistem aliran berupa rembesan (diffuse) yang cukup mendominasi. Dengan demikian dapat disimpulkan, bahwa ketika musim kemarau, Mataair Guntur tetap mengalir meskipun dalam debit yang kecil, yang berasal dari aliran dasarnya dengan karakteristik pelepasan yang lambat dan sistem aliran masih berupa rembesan. Adapun hasil pengolahan pemisahan aliran dasar dalam jangka waktu satu tahun disajikan sebagai berikut (Gambar 4 dan Tabel 3).

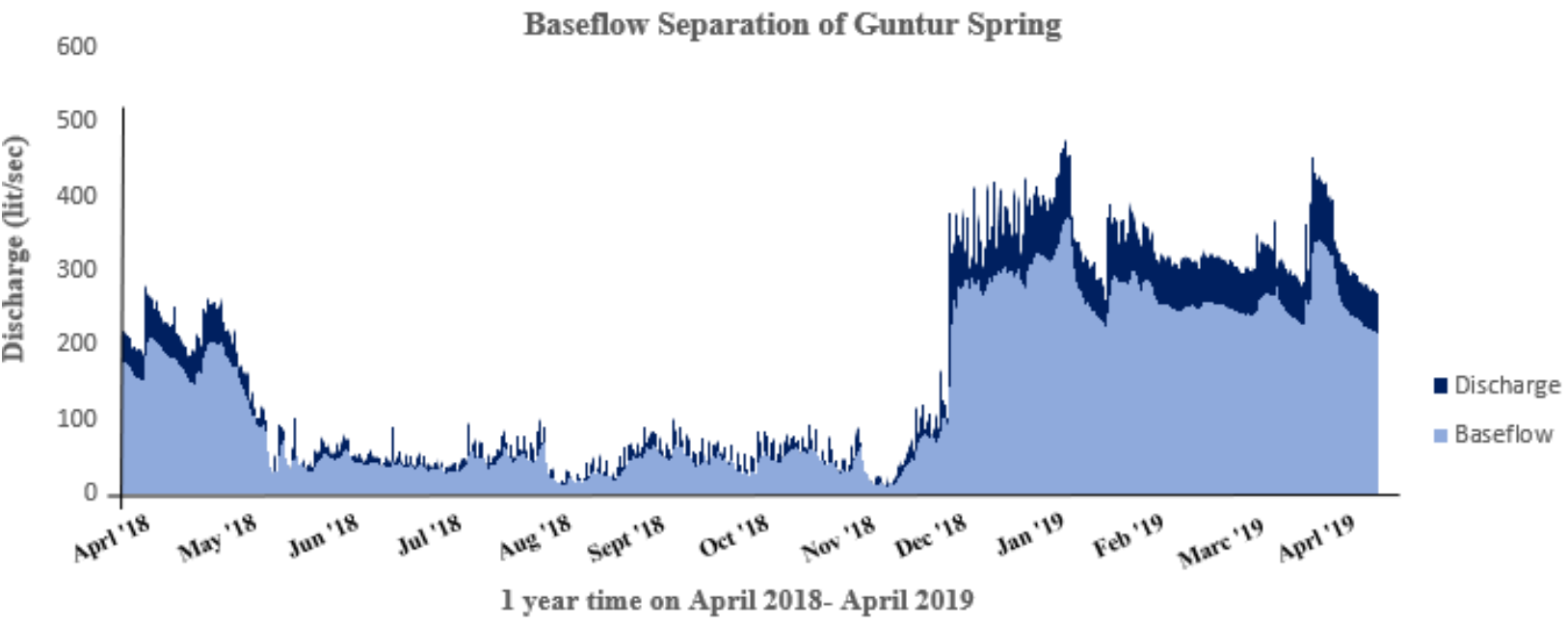

Fig 4. Baseflow separation of Guntur Spring

Tabel 3. Baseflow separation of Guntur Spring

\begin{tabular}{|c|c|c|c|c|c|}
\hline No. & Bulan & $\begin{array}{c}\text { Average of } \\
\text { discharge } \\
\text { (lit/sec) }\end{array}$ & $\begin{array}{l}\text { Average baseflow } \\
\text { (lit/sec) }\end{array}$ & $\begin{array}{c}\text { Average of } \\
\text { baseflow } \\
\text { proportion } \\
(\%)\end{array}$ & Season \\
\hline 1 & April '18 & 226.2411 & 180.99 & 80.04 & Awal kemarau \\
\hline 2 & May '18 & 96.37471 & 77.1701 & 88.38 & $\begin{array}{l}\text { Pertengahan } \\
\text { kemarau }\end{array}$ \\
\hline 3 & June ' 18 & 51.36678 & 41.09955 & 81.67 & $\begin{array}{l}\text { Pertengahan } \\
\text { kemarau }\end{array}$ \\
\hline 4 & July ' 18 & 53.65519 & 42.91158 & 82.26 & $\begin{array}{l}\text { Pertengahan } \\
\text { kemarau }\end{array}$ \\
\hline 5 & August '18 & 36.81097 & 29.45038 & 93.96 & $\begin{array}{l}\text { Pertengahan } \\
\text { kemarau }\end{array}$ \\
\hline 6 & $\begin{array}{l}\text { September } \\
' 18\end{array}$ & 60.9049 & 48.73617 & 87.78 & Akhir kemarau \\
\hline 7 & October ' 18 & 56.79415 & 45.43264 & 88.23 & Akhir kemarau \\
\hline 8 & $\begin{array}{l}\text { November } \\
\text { ' } 18\end{array}$ & 63.09037 & 50.33363 & 85.29 & Awal penghujan \\
\hline
\end{tabular}


Paper ini merupakan versi Bahasa Indonesia dari paper kami yang diterbitkan di https://www.e3sconferences.org/articles/e3sconf/abs/2019/51/e3sconf icenis2019 01014/e3sconf icenis2019010 14.html

\begin{tabular}{clcccl}
\hline $\mathbf{9}$ & December '18 & 369.846 & 295.8569 & 79.57 & Awal penghujan \\
$\mathbf{1 0}$ & January '19 & 415.6177 & 332.6371 & 80.67 & Awal penghujan \\
$\mathbf{1 1}$ & February '19 & 312.2115 & 249.7781 & 80.12 & Pertengahan hujan \\
$\mathbf{1 2}$ & March '19 & 337.0883 & 269.6732 & 80.60 & Pertengahan hujan \\
$\mathbf{1 3}$ & April '19 & 276.115 & 220.942 & 80.81 & Akhir penghujan \\
\hline \multicolumn{7}{c}{ Average } & 83.80 & \\
\hline
\end{tabular}

Sources: Data Processing (2019)

Gambar 4 menunjukkan proporsional besarnya aliran dasar dalam jangka waktu 1 tahun. Lebih lanjut dalam tabel 3 menyajikan rerata bulanan aliran dasar yang terjadi berikut dengan rerata proporsi aliran dasar tiap bulannya. Julat rerata aliran dasar yang terjadi dimulai dari $45.43264-332.637$ lit/sec. Berdasarkan hasil pengolahan data nilai rerata aliran dasar dominan lebih besar terjadi pada bulan yang termasuk pada musim awal penghujan hingga akhir penghujan dibanding pada musim kemarau. Kondisi tersebut tentu terjadi karena selama musim penghujan mataair kemungkinan besar lebih masif dalam mendapat pasokan aliran air, berbeda dengan kondisi di musim kemarau.

Adapun rerata proporsi aliran dasar per bulan, bulan yang tergolong pada musim kemarau dominan memiliki proporsi yang lebih besar dibandingkan pada musim penghujan (May- August 2018). Kondisi tersebut tentu terjadi karena pada musim kemarau aliran lebih dominan bahkan keseluruhannya hanya terdiri dari komponen proporsi aliran dasar, tanpa ada kontribusi aliran langsung (conduit). Sedangkan berbeda ketika musim hujan berlangsung, proporsi dari aliran dasar tentu akan lebih kecil karena adanya kontribusi komponen aliran langsung. Dengan demikian proporsi aliran dasar menjadi lebih besar di musim kemarau dibandingkan proporsi aliran dasar di musim penghujan. Adapun untuk mendukung pernyataan tersebut, lebih lanjut dapat dipahami melalui pemisahan aliran dasar dari banjir terpilih dalam 1 tahun sebagai berikut (Tabel 4 dan Gambar 5).

Tabel 4. Baseflow separation of selected flood event

\begin{tabular}{|c|c|c|c|c|c|}
\hline No. & $\begin{array}{c}\text { Selected } \\
\text { flood event }\end{array}$ & $\begin{array}{c}\text { Peak } \\
\text { discharge } \\
\text { (lit/sec) }\end{array}$ & Flood category & $\begin{array}{c}\text { Baseflow } \\
\text { (lit/sec) }\end{array}$ & $\begin{array}{c}\text { Baseflow } \\
\text { proportion } \\
(\%)\end{array}$ \\
\hline 1 & 07/04/2018 & 279.56 & Middle & 224.65 & 80.36 \\
\hline 2 & 08/05/2018 & 159.56 & Middle & 128.45 & 80.50 \\
\hline 3 & $19 / 06 / 2018$ & 93.56 & Low & 77.04 & 79.14 \\
\hline 4 & $26 / 06 / 208$ & 63.56 & Low & 50.05 & 78.74 \\
\hline 5 & 28/11/2018 & 209.56 & Middle & 165.25 & 78.85 \\
\hline 6 & $22 / 12 / 2018$ & 423.56 & High & 338.05 & 79.81 \\
\hline 7 & 23/01/2019 & 402.56 & High & 321.25 & 79.80 \\
\hline 8 & $18 / 03 / 2019$ & 504.23 & High & 370.88 & 73.55 \\
\hline 9 & $24 / 03 / 2019$ & 392.56 & High & 313.25 & 79.79 \\
\hline \multicolumn{5}{|c|}{ Average } & 78.94 \\
\hline
\end{tabular}

Sources: Data processing (2019)

Julat aliran dasar yang terjadi berkisar antara 50.05-370.88 lit/sec. Adanya rentang nilai cukup besar antara aliran dasar pada banjir terpilih 17 march 2019 dengan yang lainnya disebabkan karena pada waktu tersebut terdapat siklon savanna yang terjadi dan berdampak munculnya hujan dengan intensitas yang lama dan dengan curah hujan yang cukup tinggi, sehingga berimbas pada kenaikan muka air yang signifikan dan lebih lanjut pada kemelimpahan aliran dasarnya. Adapun proporsi dari aliran dasarnya, hampir sama dengan hasil rerata bulanan, pada banjir terpilih dominasi besarnya proporsi aliran dasar lebih besar pada musim kemarau yang mana pada tabel 4 diklasifikasikan dengan kategori banjir sedang hingga rendah. 
Kontribusi aliran dasar seperti yang telah dibahas sebelumnya, lebih besar proporsinya di musim kemarau dibandingkan pada waktu musim penghujan. Gambar 5 merepresentasikan blok diagram dari pemisahan aliran dasar pada setiap kejadian banjir. Pada waktu musim penghujan aliran langsung memiliki kontribusi yang lebih besar sehingga mengurangi proporsi dari komponen aliran dasar. Ditunjukkan dari digram bagian kiri hingga kekanan, yang membuktikan bahwa semakin kekanan dari blok diagram tersebut, aliran proporsi aliran dasar menjadi semakin berkurang dan proporsi dari aliran langsung (conduit) semakin meningkat. Penurunan kontirbusi aliran dasar paling signifikan dengan kontribusi aliran langsung yang paling besar dapat dilihat pada blok diagram banjir terpilih yang terjadi pada tanggal 17 th march 2019 ketika siklon savanna terjadi.

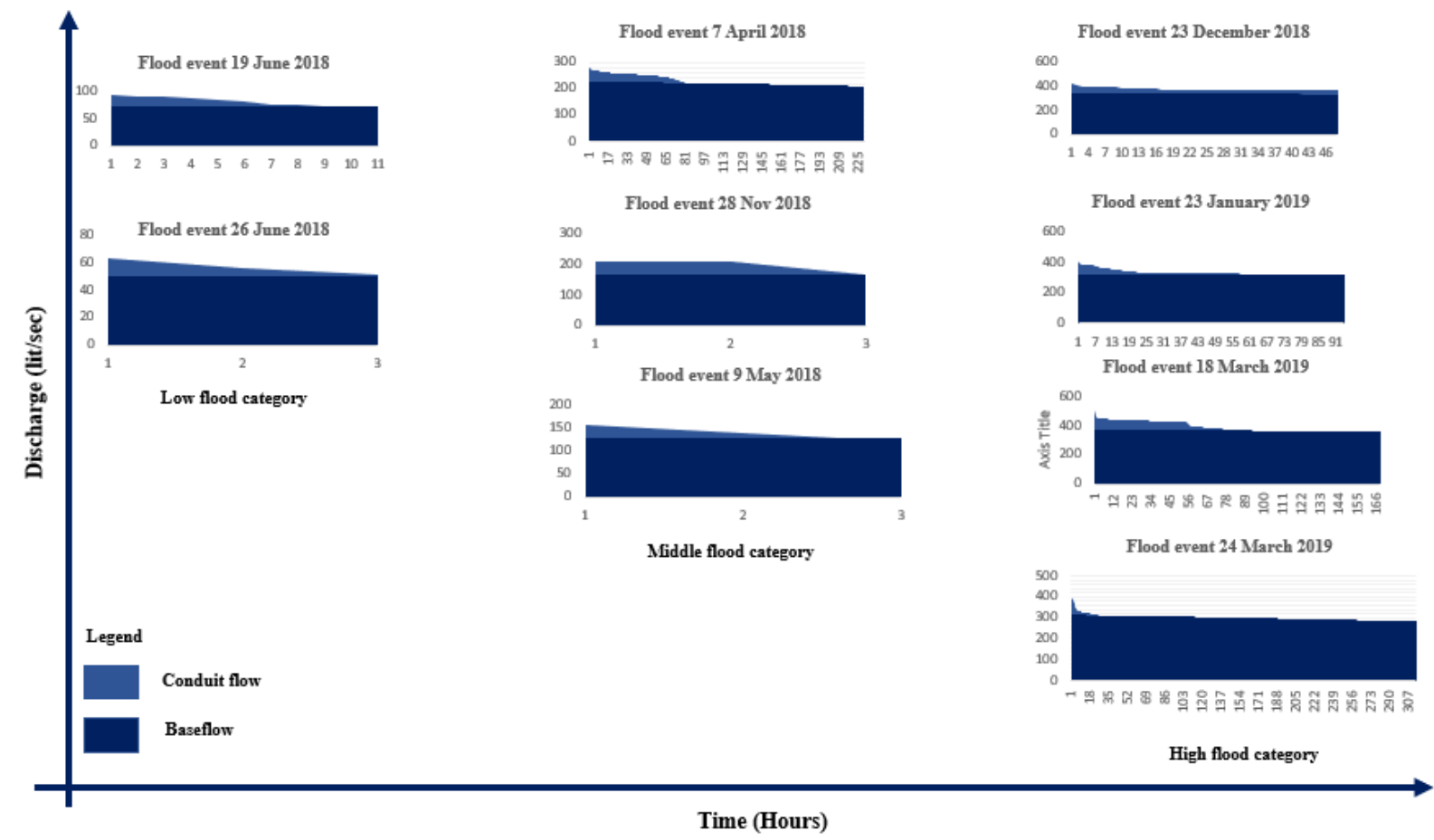

Fig. 5 selected flood event grapich of baseflow separation

\section{Conclusions}

Debit terkecil dan terbesar selama penelitian masing-masing mencapai 7.56 lit/sec dan 504.23 lit/sec, dengan debit rata-rata 169.14 lit/sec. Kecilnya rata-rata debit yang terjadi pada Mataair Guntur menjadi salah satu ciri dari pemunculan mataair yang berada pada sub-hidrogeologi Panggang di Karst Gunung Sewu. rata-rata waktu yang dibutuhkan untuk mencapai debit puncak selama 9.6 jam dengan waktu terlama sebesar 30.16 jam dan waktu tercepat selama 0.5 jam. Kondisi tersebut cukup relevan dengan kondisi banjir yang sedang berlangsung saat itu, yaitu ketika banjir pada kategori rendah hingga sedang, waktu yang dibutuhkan untuk mencapai debit puncak semakin lama, dan begitu juga sbealiknya. Adapun lamanya waktu tinggal air ( $\mathrm{Tb}$ ) rata-rata pada 152.96 jam, dengan waktu terlama pada bulan saat terjadi hujan dan banjir pada kategori yang tinggi, dibuktikan dengan waktu terlama sebesar 314.50 jam terjadi pada kejadian banjir pada tanggal 24 maret 2019. Lebih lanjut, koefisien resesi pada aliran dasar Mataair Guntur rata-rata sebesar 0.990, artinya nilai tersebut menujukkan lambatnya pelepasan komponen aliran khususnya aliran dasar pada Mataair Guntur. Lebih jauh lagi semua kondisi tersebut mencerminkan bahwa komponen aliran pada Mataair Guntur didukung dengan sistem aliran berupa rembesan (diffuse) yang cukup mendominasi. 
Julat rerata aliran dasar yang terjadi dimulai dari 45.43264 -332.637 lit/sec. Berdasarkan hasil pengolahan data nilai rerata aliran dasar dominan lebih besar terjadi pada bulan yang termasuk pada musim awal penghujan hingga akhir penghujan dibanding pada musim kemarau. Kondisi tersebut tentu terjadi karena selama musim penghujan mataair kemungkinan besar lebih masif dalam mendapat pasokan aliran air, berbeda dengan kondisi di musim kemarau.

Pada waktu musim penghujan aliran langsung memiliki kontribusi yang lebih besar sehingga mengurangi proporsi dari komponen aliran dasar. Ditunjukkan dari digram bagian kiri hingga kekanan, yang membuktikanbahwa semakin kekanan dari blok diagram tersebut, aliran proporsi aliran dasar menjadi semakin berkurang dan proporsi dari conduit flow semakin meningkat. Penurunan kontirbusi aliran dasar paling signifikan dengan kontribusi aliran langsung yang paling besar dapat dilihat pada blok diagram banjir terpilih yang terjadi pada tanggal 18 march 2019 ketika siklon savanna terjadi. Hasil analisis menunjukkan bahwa konstribusi diffuse flow di Mataair Guntur adalah antara 79,57\% sampai dengan $93,96 \%$.

\section{Acknowlegment}

This research was made possible by funding from Hibah Rekognisi Tugas Akhir, Universitas Gadjah Mada. Tim penulis mengucapkan banyak terimakasih pada kelompok studi karst yang telah banyak membantu selama lapangan hingga jurnal ini ditulis. Tim penulis juga berterimakasih kepada Fakultas Geografi, Universitas Gadjah Mada yang telah mengijinkan penelitian ini dilakukan.

\section{References}

Adji, T.N. Haryono, E. Woro, S. (1999). Kawasan Karst Dan Prospek Pengembangannya Di Indonesia. Seminar PIT IGI di Universitas Indonesia. Jakarta.

Adji, T.N. (2011). Pemisahan Aliran Dasar Bagian Hulu Sungai Bribin Pada Aliran Gua Gilap, Di Karst Gunung Sewu, Gunungkidul, Yogyakarta. Jurnal Geologi Indonesia, Vol 6 3:165-175.

Adji, T. N., Haryono, E., Fatchurohman, H., Oktama, R. (2015). Diffuse Flow Characteristic and Their Relation to Hydrohemistry Conditions in The Petoyan Spring, Gunungssewu Karts, Java, Indonesia. Geosciences Journal, DOI 10.1007/s12303-015-0048-8.

Adji, T. N., Haryono. E., Mujib A. Fatchurohman. A., Bahtiar. I. Y. (2017). Assessment of Aquifer Karstification Degree in Some Karst Sites on Java Island, Indonesia. Carbonates Evaporite DOI 10.1007/s13146-017-0403-0.

Atkinson, T.C. (1976). Diffuse Flow and Conduit Flow in Limestone Terrain in The Mendip Hills, Somerset (Great Britain). Journal of Hydrology, 35: 95-110.

Atkinson, T.C. 1985. Present and Future Directions in Karst Hydrogeology. Ann. Soc. Geoi. Belgique, 108: 293-296.

Beynen. V. P. (2011). Karst Management. New York: Springer.

Cahyadi, A.; Riyanto, A.I.; Lestari, S.F. dan Listyaningrum, N. 2018a. Peningkatan Kapasitas Masyarakat Desa Girijati, Kecamatan Purwosari, Kabupaten Gunungkidul dalam Konservasi Kawasan Karst. Laporan Hibah Pengembangan Program Pengabdian Kepada Masyarakat Fakultas Geografi UGM 2018. Yogyakarta: Fakultas Geografi Universitas Gadjah Mada.

Cahyadi, A.; Riyanto, I.; Irshabdillah, M.R. dan Firizqi, F. 2018b. Inventarisasi dan Karakterisasi Sistem Aliran Sungai Alogenik di Kawasan Karst Gunungsewu Kabupaten Gunungkidul. Laporan Hibah Penelitian Dosen Fakultas Geografi UGM 2018. Yogyakarta: Fakultas Geografi Universitas Gadjah Mada.

Riyanto, I., Cahyadi, A., Adji, T.A., Haryono, E., Widyastuti, M., Agniy. R.F., Wilda, A.F., Rahmawati N., dan Baskoro, H. (2015). Analisis Konektivitas Dan Karakterisasi Pelorongan Dengan Uji Perunutan Pada Mataair Epikarst Sub-Sistem Panggang, Kawasan Karst Gunungsewu. Pekan Ilmiah Tahunan Perhimpunan Ahli Airtanah Indonesia (Paai) Yang Diselenggarakan Di Hotel Aryaduta, Jakarta, 7 - 8 November 2018. 
Eckhardt, K, 2005. How to Construct Recursive Digital Filters for Baseflow Separation. Hydrological Processes, 19: 507- 515.

Ford, D. C., and Williams, P. W. (2007), Karst Hydrogeology and Geomorphology, Chichester: Wiley. Haryono E, Day M 2004 Landform differentiation within the Gunung Kidul Kegelkarst, Java, Indonesia Journal of Cave and Karst Studies 662 62-69.

Haryono, E. 2011. Introduction to Gunungsewu Karst. Field Guide of Asian Trans-Disciplinary Karst Conference. Yogyakarta: Karst Research Group, Faculty of Geography, Universitas Gadjah Mada.

Kusumayudha, S.B., 2002, Sistem Hidrogeologi Gunungsewu. Prosiding Sumberdaya Geologi Daerah Istimewa Yogyakarta dan Jawa Tengah. Ikatan Ahli Geologi Indonesia (IAGI) Pengda DIY-Jateng, pp $130-141$.

Milanovic, P. 2015. Optimal Water Management - Prerequisite for Regional Socio-Economic Development in The Karst of The South-Eastern Dinarides. International Association of Hydrogeologists Selected Papers : Karst without Boundaries

Schulz, E.F. 1976. Problems in Applied Hydrology. Colorado: Water Resources Publication.

Oktama, R. 2014. Karakterisasi Akuifer Karst Mataair Ngeleng dengan Pendekatan Variasi Temporal Sifat Aliran dan Hidrogeokimia. Skripsi. Yogyakarta: Fakultas Geografi UGM.

Widyastuti, M., Riyanto, I.A., Naufal, M., Ramadhan, F., dan Rahmawati, N. 2018. Water Catchement Area Analysis of Guntur Karst Spring. Proceeding. The 2nd International Conference on Environmental Resources Management in Global Region. Yogyakarta 22-23 Oktober 2018.

White, W.B. (1969). Conceptual Models for Carbonate Aquifers. Ground Water, 7 (3).

Wijayanti, P., Haryono, E. Hadi, P. (2017). Water Balance in Epikarst: Case study of Kakap Springs, the Eastern Karst of Gunungsewu. 1st UPI International Geography Seminar, doi :10.1088/1755$1315 / 145 / 1 / 012088$ 